DOI: https://doi.org/10.24144/2409-6857.2018.1(51).28-37

УДК 338.025.2

Жулканич В.O.

\title{
ЕКОЛОГО-ЕКОНОМІЧНІ Й ОРГАНІЗАЦІЙНІ ВАЖЕЛІ УПРАВЛІННЯ ПРИРОДОКОРИСТУВАННЯМ
}

\begin{abstract}
У статті узагальнено основні еколого-економічні й організаційні важелі стратегії управління природокористуванням транскордонного регіону, які сприяють утвердженню $i$ реалізації положень екологічних $i$ економічних законів у сфері природокористування. Обтрунтовано сукупність $i$ дію зазначених важелів в системі раціонального природокористування, охорони навколишнього середовища $i$ забезпечення здоров'я населення. Наголошено на проблемах їх адаптації у ринковому середовищі, окреслено вплив важелів на екосистеми та використання природних ресурсів. Значна увага приділена впровадженню інноваџійних напрямів господарювання, використанню результатів комплексного моніторингу і обліку природних ресурсів регіону, удосконаленню нормативно-правової бази Концепції та програм раціонального природокористування.
\end{abstract}

Ключові слова: еколого-економічні й організаційні важелі, управління природокористуванням, комплексний моніторинг, капіталізація природних ресурсів, охорона довкілля, платежі за ресурси.

Постановка проблеми. В умовах формування та утвердження ринкових відносин господарювання важлива роль належить запровадженню нових підходів до управління процесами природокористування. Актуальності набувають еколого-економічні важелі стратегії такого управління в системі природогосподарського комплексу країни, направлені на екологізацію його розвитку з метою забезпечення раціонального природокористування, охорони навколишнього середовища і забезпечення здоров'я населення. Йдеться, зокрема, про забезпечення цілеспрямованої діяльності пов'язаної 3 використанням найбільш життєво необхідних для людства природних ресурсів, свідомим впливом на екосистеми та природні процеси.

Викладені вище завдання відображені в Програмах соціально-економічного розвитку країн $\mathrm{i}$ регіонів. Зокрема, у програмі "Свропа - 2020. Стратегія розумного, стійкого і всеосяжного зростання" [10], Європейська Комісія запроваджує сім флагманських ініціатив, серед яких "Ресурсоефективна Європа", де задекларована мета допомогти відокремити економічне зростання від використання ресурсів. Ця ініціатива передбачає перехід до низьковуглецевої економіки, ширше використання поновлюваних джерел енергії, розвиток екологічно чистих технологій, створення модернізованого транспортного сектору і конкурентоспроможної економіки.

В Програмі - 2020 наголошено, що країни Свропейського Союзу можуть розраховувати і на

(c) Жулканич Віктор Олександрович, аспірант кафедри міжнародних економічних відносин, ДВНЗ «Ужгородський національний університет», м. Ужгород існуючі демократичні інститути, соціальну та територіальну єдність, позицію $Є \mathrm{C}$ щодо охорони та збереження навколишнього середовища.

Програма “Свропа - 2020” важлива не тільки для країн-членів $€ C$, а й для країн-кандидатів в члени спільноти, оскільки програма може стати провідником для цих країн у питаннях реформування. Крім того, однією 3 найважливіших цілей в найближчі роки стане побудова стратегічних відносин 3 країнами 3 економікою, що розвивається. Отже, положення програми “Свропа-2020" є актуальними для адаптації i впровадження в Україні.

В цьому контексті для України постає завдання організації науково-обгрунтованого i еколого безпечного господарювання, створення у виробників економічної зацікавленості у здійсненні природоохоронних заходів i економічної відповідальності за порушення існуючих правил і норм природокористування.

Аналіз останніх досліджень i публікацій. Дослідження сучасних механізмів управління охороною навколишнього середовища України, екологічних основ природокористування знайшли відображення у працях науковців В. Борисової, І. Гайдуцького, О. Ходаківської, Б. Данилишина, М. Хвесика та ін. [1, 3, 4, 5, 8]. Однак, питання еколого-економічних й організаційних важелів управління природокористуванням висвітлені ними не в повній мірі. Тож, на нашу думку, потребують більш детального розгляду.

Формулювання цілей статті. Мета статті узагальнення, обгрунтування i дія еколого економічних й організаційних важелів управління природокористуванням. 
Планування та прогнозування процесів природокористування

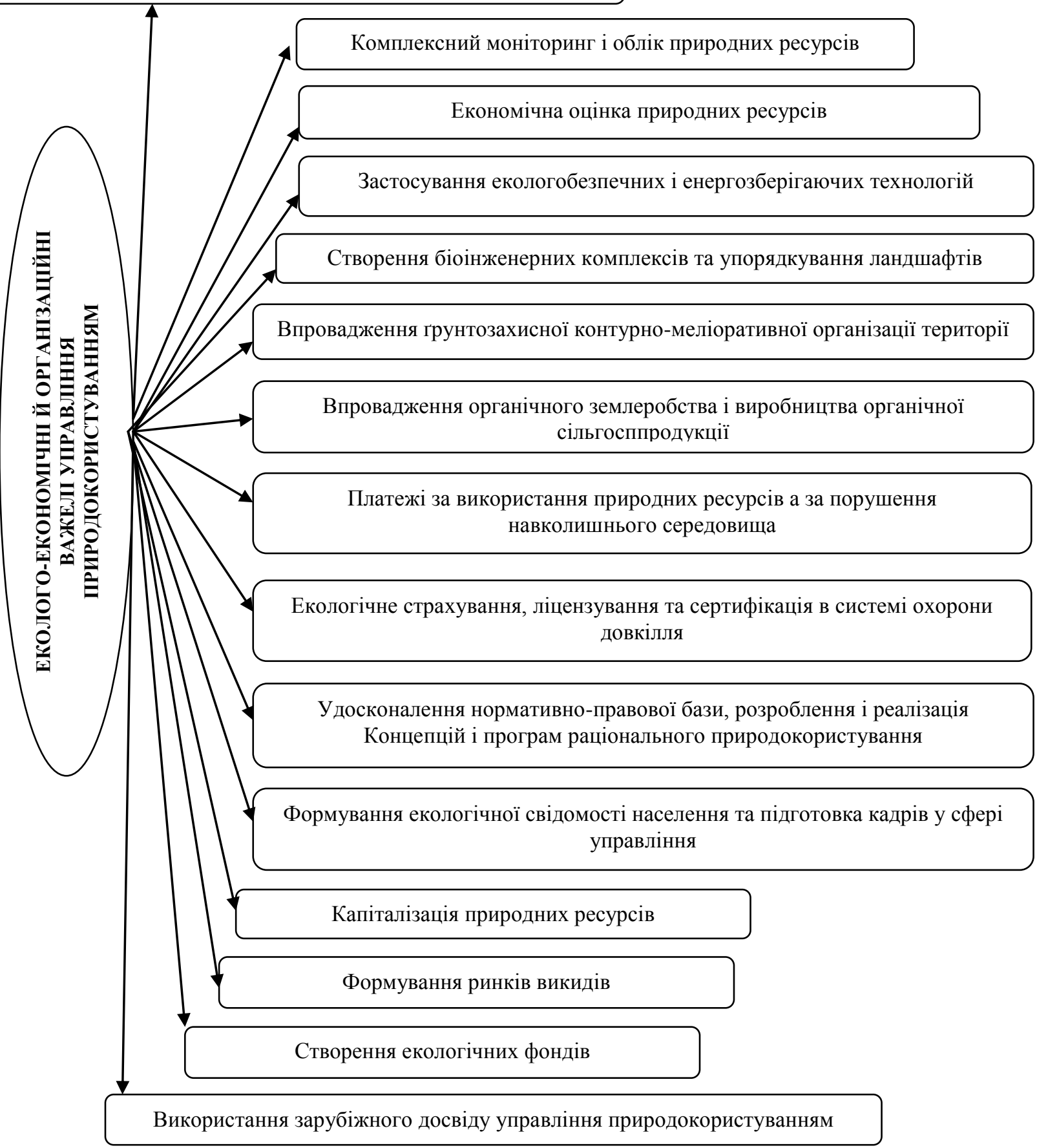

Рис. 1 Еколого-економічні й організаційні важелі управління природокористуванням*

*Розроблено автором

Опис основного матеріалу дослідження. В результаті проведених досліджень автором узагальнено i обгрунтовано дію наступних еколого-економічних важелів управління природокористуванням (рис.1):

Планування та прогнозування процесів природокористування взаємопов'язаних планових дій та специфічних стратегій щодо забезпечення найсприятливіших екологічних умов життедіяльності суспільства шляхом економного i комплексного використання та відтворення природних ресурсів, а також зменшення забруднення довкілля [7, с.105].

Основні завдання планування і прогнозування природокористування: розроблення державних кадастрів природних ресурсів, державних програм раціонального використання i відтворення природних ресурсів, формування i планування реалізації еколого-економічних 
заходів щодо природокористування i охорони довкілля.

3 метою узгодження програм 3 природокористування та охорони навколишнього середовища 3 програмами соціально-економічного розвитку транскордонних регіонів застосовуються наступні методи: балансовий, нормативний, програмно-цільовий. В процесі застосування названих методів встановлюються ліміти нормативної плати i розміри платежів за використання природних ресурсів. Прогнозне планування передбачає вдосконалення економічного механізму природокористування, трансформації існуючої системи планування, як природоохоронних заходів, так і раціонального використання природних ресурсів.

Зокрема, розвиток механізму економічного стимулювання раціонального використання природних ресурсів та охорони природи в аграрній сфері потребує впровадження економічного стимулювання інтенсивності та ефективності землекористування i сільськогосподарського виробництва.

У свою чергу сучасний механізм економічного стимулювання раціонального природокористування в аграрній сфері України характеризується державним втручанням в реалізацію процесу природокористування та сільськогосподарського виробництва 3 метою збільшення виробництва сільськогосподарської продукції й досягнення продовольчої безпеки.

Комплексний моніторинг і облік природних ресурсів у сфері природокористування застосовують екологічний моніторинг: систему спостережень, збирання, опрацювання, передавання, аналіз, прогнозування і збереження інформації про стан навколишнього природного середовища та зміни його природних і природноантропогенних комплексів, ресурсів і процесів 3 метою раціонального природокористування i природовідтворення. Моніторинг навколишнього природного середовища грунтується на загальноекономічних законах i принципах iз застосуванням загальнонаукових методів дослідження (аналіз, синтез, узагальнення, статистична обробка інформації, моделювання, тощо) [6,с.315].

Згаданий моніторинг проводиться в три етапи досліджень: спостереження, оцінка екологічно ситуаціі, прогнозування екологічних умов. В Україні спостереження здійснюють різні спеціально уповноважені державні установи: Міністерство охорони здоров'я контролює стан атмосферного повітря, Міністерство аграрної політики та продовольства здійснює контроль за станом біологічних та земельних ресурсів. Одержані результати моніторингових досліджень i інформація про стан довкілля використовується в процесі розробки державних i регіональних програм i заходів щодо оздоровлення навколишнього природного середовища, сприяють забезпеченню раціонального використання і відтворення природних ресурсів.

Економічна оцінка природних ресурсів визначення суспільної (економічної, соціальної, екологічної, тощо) корисності (цінності, внеску) ресурсу в підвищення рівня задоволення суспільних потреб через виробництво i споживання, виражене в грошовому вимірі. Здійснюється вартісна оцінка природних ресурсів, задіяних у процесі використання та відтворення, а також, вартісна оцінка природних ресурсів, що не беруть безпосередньої участі у виробничих процесах, але необхідні для життєдіяльності суспільства 3 врахуванням задоволення майбутніх потреб людства. Оцінку проводять 3 використанням наступних складових: ринкової оцінки, ренти, витратного підходу, альтернативної вартості, загальної економічної цінності (вартості) [9,с.682].

Важливим в системі економічної оцінки природних ресурсів $€$ вибір оптимальних параметрів експлуатації природних ресурсів, визначення розмірів збитків від нераціонального i некомплексного використання природних ресурсів, визначення економічної ефективності інвестицій у природно-рекреаційний сектор, відображення оцінки частки природних ресурсів у структурі національного багатства [5, с.105].

Сферою застосування результатів оцінок природних ресурсів $\epsilon$ : ведення кадастрів природних ресурсів; аналіз внеску кожного виду ресурсу до складу національного багатства України; оцінка економічної ефективності функціонування галузей, підприємств, організацій, пов'язаних із використанням, відтворенням і охороною природних ресурсів; визнання та формування обгрунтованих нормативів використання природних ресурсів 3 метою забезпечення максимальної екологоекономічної ефективності суспільного виробництва; формування нормативів економічного стимулювання підприємств й організацій, що використовують природні ресурси [12, с.40].

Потреба мати всебічну економічну оцінку наявних в транскордонному регіоні різних видів природних ресурсів, їх повна кількісна і якісна характеристика забезпечить засади сучасного i перспективного раціонального їх використання i відтворення. За таких умов досягають повсюдної екологізації виробництва, нагромадження коштів на екологічне оздоровлення навколишнього 
середовища. Важливим є усвідомлення того, що саме навколишне середовище разом 3 природними ресурсами є основною складовою продуктивних сил суспільства, своєрідним фундаментом їх розвитку, а людина як частина живої природи, як продукт суспільства і головна продуктивна сила знаходить умови для життєдіяльності і ведення виробництва.

Застосування енергозберігаючих впровадження

екологобезпечних технологій передбачає нових екологобезпечних виконання управлінських та інших рішень спрямованих на досягнення ефективності використання природних ресурсів 3 одночасним збереженням природного середовища та його поліпшення. В свою чергу, енергозберігаючі технології спрямовані на зниження споживання та витрату енергоресурсів в результаті реалізації програм енергозбереження i виробництва продукції.

У сфері раціонального природокористування важлива роль належить розвитку альтернативної енергетики, що базується на використанні відновлюваних джерел енергії: сонячної, геотермальної, вітрової, гідравлічної, а також біогазу. Переваги альтернативної енергетики на відміну від традиційної енергетики, що використовує вугілля, нафту, газ, торф, дрова і одним із джерел забруднення навколишнього середовища, в тому, що альтернативна енергетика $є$ запорукою екологічного виробництва.

Узагальнення наукових досліджень підтверджує, що економічні важелі, які спроможні перетворити нераціональне природокористування на раціональне, тісно пов'язані 3 необхідністю здійснювати постійну обов'язкову плату за природні ресурси та пошкодження навколишнього середовища. Підвищена плата за використання природних ресурсів i охорону довкілля економічно змушує природокористувачів впроваджувати у виробництво ресурсозберігаючі, мало- та безвідходні технології, здійснювати ефективні заходи щодо охорони навколишнього середовища.

Створення біоінженерних комплексів та упорядкування ландиафтів. Ландшафт як частина земної поверхні $з$ певним сполученням рельєфу, клімату, грунтів, рослинного і тваринного світу, атмосферного повітря і створеною людиною різноманітною сельбищною та виробничо-технічною інфраструктурою суттєво впливає на види i технології природокористування.

До численних земних ландшафтів входять природні, різною мірою змінені діяльністю людини (природно-антропогенні, техногенно перетворені), і відновлені (ренатуралізовані), територіальні (суходільні-наземні й наземноаквальні) та акваторіальні (морські) комплекси, що разом утворюють ландшафтну оболонку землі [6, с.227]. В системі природокористування всі види ландшафту потребують упорядкування, оскільки ландшафти територіальних комплексів $\epsilon$ екосередовищем діяльності людства і всього живого на землі, місцями прояву екологічних проблем та основою природоохоронних об'єктів і формування екомереж.

Особливо це стосується удосконалення системи облаштування території, забудови i використання земель сільських територій, їх ландшафтно-екологічної структуризації. 3 метою забезпечення раціонального використання, охорони i відтворення природних ресурсів транскордонних регіонів доцільним $є$ створення на їх територіях біоінженерних комплексів, поширення їх функціонування на прикордонні території суміжних країн.

Впровадження грунтозахисної контурномеліоративної організацї території, яку застосовують в умовах складного рельєфу для зменшення небезпеки прояву ерозійних процесів та екологобезпечного використання земельних ресурсів. Впровадження такої грунтозахисної системи є характерною для Закарпатської області як транскордонного регіону, де $2 / 3$ території гориста місцевість.

В умовах сучасного інтенсивного ведення сільськогосподарського виробництва, коли існує посилена дія антропогенних факторів на стан продуктивних земель на фоні існуючих природ них факторів, важливого значення набуває вибір основних напрямів природоохоронної діяльності суб'єктів-землекористувачів, зокрема оптимізація структури землекористування, впровадження грунтозахисної системи землеробства та зниження антропогенного забруднення агроекосистем.

В процесі проведення земельної реформи, коли формуються нові ландшафти i системи землеробства, значення контурно-меліоративнлї системи землеробства зростає. Контурно-меліоративна система господарювання передбачає створення системи лісосмуг, гідротехнічних регулюючих i земляних валів різних типів, буферні смуги 3 багаторічних трав, тощо. Формується екологічно-стійка контурно-смужна структура агроландшафтів, яка забезпечує зарегулювання поверхневого стоку, контроль над ерозійними процесами та оптимальне поєднання системи сільськогосподарського землекористування з природним середовищем. 
Контурна організація території повинна здійснюватися 3 пріоритетом природоохоронної організації території агроландшафту над адміністративними та господарськими межами 3 урахуванням смугової структури природних комплексів і меж між землями різного типу використання. 3 метою раціонального використання орної землі постає завдання переходити від рівнинно-прямолінійного до контурно-меліоративного землекористування.

Впровадження органічного землеробства $i$ виробництва органічної сільгосппродукції (сировини). Розроблені Міжнародною федерацією органічного руху (IFOAM) принципи органічного сільського господарства $\epsilon$ наступними: оздоровлення; екології; справедливості; турботи [18].

В Україні виробництво органічної продукції перебуває на початковому етапі розвитку. Принципи виробництва, зберігання, перевезення та реалізації органічної продукції (сировини) відображені в Законі України "Про виробництво та обіг органічної сільськогосподарської продукції та сировини" [14]. Серед основних принципів: добровільності; рівності прав суб'єктів господарювання, які здійснюють виробництво, зберігання, перевезення та реалізацію органічної продукції (сировини); раціонального використання природних ресурсів, забезпечення їх належного використання та відтворення; довгострокового підтримання родючості грунту; використання живих організмів та методів механічного виробництва; забезпечення високого рівня біологічного різноманіття.

Дотримання вище викладених принципів органічного землеробства забезпечує реалізацію соціально-економічних чинників аграрного господарювання, екологізацію сільського господарства, раціонального використання природних ресурсів 3 поєднанням завдань збереження навколишнього природного середовища і задоволення потреб населення в споживанні екологічно безпечних харчових продуктів.

Платежсі за використання природних ресурсів та за порушення навколишнього середовища. Платне природокористування здійснюється згідно з відповідними нормативами плати як окремої складової платежів за спеціальне використання природних ресурсів, плати за погіршення якості природних ресурсів та за забруднення навколишнього середовища. Збори за спеціальне використання природних ресурсів справляють 3 метою стимулювання раціонального використання, охорони та відтворення природних ресурсів. Платниками зборів за спеціальне використання природних ресурсів є підприємства, установи та організації незалежно від форми власності, а також громадяни-підприємці, яким природні ресурси надаються у володіння, користування або оренду.

В системі плати за порушення навколишнього середовища діє принцип “забруднювач платить”. Плата стягується згідно 3 тарифами і нормативами за обсяги завданих збитків довкіллю з врахуванням витрат на їх відшкодування. Існують певні ліміти на суми збору, які справляються за викиди стаціонарними джерелами забруднення, скиди та розміщені відходи. Діють певні стимули і пільгове оподаткування, якщо підприємства переходять на маловідходні та енергозаощаджувальні технології, встановлюють обладнання для повторного використання або переробки, впроваджують інструменти контролю за скидами забруднювачів.

Згідно з науковими узагальненями, екологічні податки є низько ефективними як за впливом на скорочення вуглецевих викидів, так i на інвестування енергоконверсії. Рівень екологічних податків, прописаний в Податковому Кодексі, становить всього 0,4 \% ВВП. Це найнижчий показник серед країн Європи [3, с.448]. Як наслідок, витрати на охорону навколишнього середовища незначні і теж на порядок нижчі, ніж у країнах Європи.

Отже, оподаткування природних ресурсів $\epsilon$ сильним стимулом до зменшення їх споживання, скорочення викидів вуглецю і мотивацією для модернізації підприємств - природокористувачів. 3 метою запобігання порушення навколишнього середовища постає завдання удосконалення податкової екологічної політики, наближення екологічних платежів до розмірів екологічної шкоди, спрямування податкової системи до стимулювання комплексного відтворення i використання природних ресурсів.

Екологічне страхування, ліщензування та сертифікація в системі охорони довкілля. Екологічне страхування передбачає акумулювання коштів для проведення природоохоронних (протиаварійних) заходів в результаті аварійних ситуацій, раптових, ненавмисних забруднень навколишнього середовища. Страхове відшкодування 3 добровільного екологічного страхування включає: компенсацію збитку, викликаного ушкодженням або знищенням майна; суму збитків, пов'язаних з погіршенням умов життя та навколишнього середовища; витрати на очищення забрудненої території і приведення іï до стану, що відповідає нормативам; витрати, 
необхідні для порятунку життя та майна осіб, яким у результаті страхового випадку заподіяні збитки або для зменшення їх шкоди [1,c.257].

Важливим елементом адміністративноправового управління в галузі охорони навколишнього середовища і природних ресурсів $\epsilon$ ліцензування, яке передбачає певні обмеження щодо користування природними ресурсами. Особливим засобом охорони і відтворення природноресурсного потенціалу нормативнотехнічного i правового регулювання екологічної безпеки $є$ екологічна сертифікація, яка слугує попередженню негативного впливу на умови життєдіяльності людини і на стан навколишнього середовища процесів виробництва та утилізації відходів. Складовою системи сертифікації є розроблений екологічний паспорт (сертифікат) підприємства, в якому відображено інформацію про використання природних ресурсів і вплив виробництва на довкілля.

Капіталізація природних ресурсів. В умовах забезпечення сталого соціально-економічного розвитку територій країни, в тому числі i транскордонних регіонів, важливою проблемою $\epsilon$ створення можливостей ефективного управління використанням територіальних ресурсів. В свою чергу, системне забезпечення підвищення вартості наявних територіальних ресурсів тісно пов'язане 3 використанням фінансових ресурсів на потреби сталого розвитку. В цьому контексті, капіталізація являе собою процес зростання ринкової вартості активів, які перебувають у власності суб'єктів економічної діяльності та (або) розміщені на певній території. Отже, завдання капіталізації полягає у залученні ресурсів (у т.ч. природних) у процес суспільного виробництва 3 їх подальшим перетворенням у вартість, що створює додану вартість [2].

Сучасна ефективна управлінська система в економічних умовах, на засадах гармонізації суб'єктів господарювання передбачає формування фінансового механізму перетворення факторів виробництва в капітал 3 метою використання природних ресурсів для відтворення якісного соціального, економічного та екологічного стану територіального простору [11,c.19]. В регіональному зрізі функціонування природно-ресурсного потенціалу породжує дохід у вигляді природно-ресурсної ренти, котра перерозподіляється між центром і регіоном через систему міжбюджетних відносин, фінансово-податкових процедур, тощо і частково повертається назад до складу локальних ресурсів території в якості іï фінансових ресурсів (бюджетних, інвестиційних, кредитних) [11,с.135].
В процесі управління капіталізацією природних ресурсів застосовують проектний підхід, як особливу форму менеджменту, в рамках інвестиційно-інноваційного способу господарювання щодо організації природокористування. Формуються i реалізуються відповідні інвестиційні господарські проекти на базі певної природноресурсної територіальної економічної системи. Процес капіталізації природних ресурсів базується на системі інформаційного забезпечення про фінансовий стан суб'єктів господарювання територіальних систем, зокрема різної економічної, комерційної, фінансової та іншої інформації.

Удосконалення нормативно-правової бази, розробка і реалізація Концепцій і програм раціонального природокористування. Збалансоване та раціональне природокористування грунтується на досконалій нормативно-правовій базі. Основні норми екологічного законодавства закріплені в прийнятій у 1996 р. Конституції України, а також у спеціальному розділі "Екологічна безпека" Декларації про державний суверенітет України (1990р.). В Конституції задекларовано право кожного громадянина користуватися природними об'єктами права власності народу відповідно до закону, право кожного на безпечне для життя i здоров'я довкілля та на відшкодування завданої порушенням цього права шкоди.

В Україні сформована солідна нормативноправова база природо-ресурсного законодавства, в якій відображено положення щодо економічноправового регулювання процесів природокористування, зокрема використання й відтворення природних ресурсів та охорони навколишнього середовища. Конституційні екологічні права громадян розлого викладені в Законі України "Про охорону навколишнього природного середовища" [15].

Виконання Законів та законодавчих актів України у сфері природокористування та охорони навколишнього середовища перекликається 3 реалізацією міжнародних Конвенцій щодо охорони довкілля. Україною ратифіковано міжнародні Конвенції «Про транскордонне співробітництво в галузі озхорони природи між громадами та владою» (1980 р.), «Про охорону біологічного різноманіття» (1994 р.), «Про охорону дикої природи, фауни i природних середовищ існування в Європі» (1996 р.), «Про речовини, що руйнують озоновий шар» (1996р.).

Разом 3 тим, реалізація зазначених Концепцій та Програм залежить від фінансової складової стратегічного управління екологічними програмами. Серед основних чинників, які 
знижують ефективність фінансового забезпечення екологічних програм наступні:

- відсутність узгодженої системної політики щодо фінансового забезпечення екологічних програм з боку центральних та місцевих органів державного управління;

- недостатня гнучкість фінансових механізмів коригування у прцесі виконання середньо - та довгострокових програм, насамперед, необхідність врахування їх недофінансування упродовж попередніх років при формуванні бюджетів усіх рівнів;

- розпорошення коштів між значною кількістю екологічних програм, зокрема, на регіональному рівні;

- обмеженість фінансових ресурсів та скорочення частки капітальних інвестицій природоохоронного значення у загальних обсягах капітальних інвестицій в основний капітал [8, с.221].

Нині невідкладними є заходи щодо удосконалення екологічного та природоресурсного законодавства, нормативно-правової бази України, адаптації законодавства України про охорону навколишнього середовища до європейської правової, нормативно-методичної та організаціної бази, синхронізації його базових засад 3 вимогами Кіотського протоколу та міжнародних Конвенцій регіонального природокористування та охорони довкілля.

Формування ринків викидів. Одним із охоронних заходів економічного регулювання природокористування в системі раціонального використання природно-ресурсного потенціалу $\epsilon$ метод формування ринків викидів. Він базується на розподілі дозволів на забруднення між підприємствами 3 правом їх передачі. В охороні навколишнього середовища все більшого значення набуває міжнародна торгівля квотами на викиди. Зокрема важливою умовою сталого низьковуглецевого розвитку національних економік є організація вуглецевого ринку, який передбачає вільну купівлю-продаж прав (дозволів) на вуглецеві викиди. Провідні країни Організації економічного співробітництва та розвитку заснували систему торгівлі викидами, яка отримала статус міжнародної [16].

Згідно з вимогами Кіотського протоколу на міжнародному рівні запроваджено квотування викидів вуглецю, що передбачає можливість торгівлі цими квотами, тобто формування глобального ринку викидів парникових газів (вуглецевого ринку). Виручені на ринку кошти $\epsilon$ джерелом фінансування заходів 3 енергоконверсії і скорочення викидів. Запровадження міжнародних кіотських механізмів слугує формуванню системи мотивації до низьковуглецевого розвитку. В свою чергу, низьковуглецевий розвиток може бути забезпечений шляхом тотальної енергоконверсії, що охоплює енергоощадність, енергомодернізацію та енергоінноваційність економічних процесів [3, c. 13].

Створення екологічних фондів. Однією зі складових механізму фінансування природоохоронних програм в умовах дефіциту державних коштів стали екологічні фонди. Головне завдання позабюджетних екологічних фондів акумулювання незалежних від державного бюджету коштів i фінансування за їх рахунок природоохоронної діяльності. Кошти фондів виступають як доповнення до бюджетного фінансування. Однак наявність значної кількості місцевих фондів призводить до розпорошення коштів та втрати контролю за їх цільовим використанням.

Для України доцільним було б реорганізувати систему екологічних фондів відповідно до адміністративно-територіального поділу Національний екологічний фонд, обласні екологічні фонди та окремо - для містмільйонників. Це дозволить акумулювати зібрані кошти й проводити масштабніші заходи 3 охорони довкілля, а також посилити контроль за їх цільовим використанням.

Україні варто запозичити досвід функціонування екологічних фондів у сусідніх державах - Угорщині, Словаччині, Польщі, де згадані фонди активно діють у сфері кредитування та субсидіювання освітніх екологічних програм; моніторингу довкілля; проведення екологічних експертиз та ін. Нині в Україні назріла необхідність формування екологічних банків, оскільки одержати кредит на природоохоронні заходи в звичайних банках складно через тривалий термін окупності коштів.

Тож, в умовах імплементації Директиви ЄС в сфері охорони довкілля України, що передбачає дотримання жорсткіших екологічних стандартів, а відтак і збільшення витрат підприємств на здійснення природоохоронних заходів, актуалізуються проблеми пошуку джерел їх фінансування.

\section{Використання зарубіжного досвіду управління природокористуванням. \\ В системі забезпечення управління} природокористуванням важливе місце належить використанню зарубіжного досвіду. В країнах Західної Європи утвердилася тенденція до звуження прямого державного управління у природоохоронній сфері й поступового переходу до більш широкого використання ринкових механізмів управління та механізмів, що 
дозволяють активізувати участь громадян i підприємств у охороні навколишнього середовища [13, с. 275].

Незважаючи на наявність вагомої законодавчої та нормативно-правової бази природоохоронної діяльності, в Україні не вдається забезпечити ii дієвість та знизити негативний антропогенний вплив на довкілля. У цьому зв'язку варто звернути увагу на досвід європейських країн. А особливо сусідніх 3 Україною, яким довелося так само пройти перехідний період в економіці, подолати труднощі руйнації командно-адміністративної системи й переходу до ринкових відносин. В результаті в сусідніх - Угорщині, Словаччині, Польщі та Румунії вдалися до звуження безпосереднього державного управління у сфері охорони навколишнього природного середовища, замістивши його ринковими механізмами із широкою участю громадськості у вирішенні природоохоронних проблем. Регулювання у сфері охорони довкілля зосереджено на рівні регіонів та місцевих органів влади, там де зосереджені економічне та соціальне життя населення.

В СС загалом, та в перелічених вище країнах зокрема, існує взаємозв'язок між загальними компетенціями природоохоронних структур (на загальноєвропейському та національному рівнях) та “обов’язками регіональних та місцевих громад щодо практичного вирішення актуальних та перспективних задач» [17,c.18]. Забезпечити цей взаємозв'язок природи і суспільства вдається завдяки поширенню екологічних знань i вихованню усвідомлення відповідальності за збереження довкілля кожним громадянином; завдяки наявності реальної можливості місцевими громадами відстоювати свої екологічні інтереси та права через суд; наявності стимулюючих економічних інструментів екологічного регулювання - кредитування природоохоронних заходів та пільгового оподаткування товаровиробників, що застосовують ресурсозберігаючі технології; запровадженню екологічного акцизного збору на екологічно шкідливі товари та податку за виробництво шкідливої продукції та ін. Україні доцільно проаналізувати й запозичити позитивний досвід вирішення проблем управління природокористуванням в сусідніх країнах оскільки, в нашій державі нині наявні значні неузгодженості між задекларованими екологічними нормами та їх реалізацією, між загальнодержавною екологічною політикою та здійсненням іiі на місцях.

Основною філософією та принципами системи управління навколишнім середовищем в країнах ЄC $\epsilon$ постійне вдосконалення взаємовідносин суспільства й природи; зменшення антропогенного навантаження та покращення екологічної безпеки довкілля.

Найбільш вартим уваги для запозичення, на нашу думку, є зарубіжний досвід поєднання збалансованих адміністративно-контрольних та фінансово-економічних важелі, які дозволяють ефективно регулювати питання охорони навколишнього природного середовища та забезпечити дієвість механізмів управління охороною довкілля.

Формування екологічної свідомості населення та підготовка кадрів у сфері управління природокористуванням. В процесі раціонального використання і відновлення природних ресурсів існує прямий зв'язок між добробутом суспільства i природним середовищем, а також ставленням людей до природи. Виникає об'єктивна необхідність активізації позитивних форм взаємодії людини і природи, формування екологічної свідомості. Вирішення проблем формування екологічної культури населення вимагає поєднання досягнень екологічного виховання, освіти та науки.

Як наголошують науковці [4,с.6]: “Екологічна культура це, насамперед, внутрішня суть людини та людського суспільства, яка проявляється у сукупності певних дій, технологій, методів та способів освоєння природи людиною та їх взаємодії, що забезпечують стійку рівновагу в системі “людина-довкілля”. Слід також, враховувати дію соціальних, фінансових, економічних, технологічних чинників на розв'язання екологічних проблем суспільства, на підвищення його екологічної свідомості".

У сфері природокористування та охорони навколишнього середовища важливою $\epsilon$ підготовка кадрів спеціалістів. Як наголошено в Програмі "Порядок денний на XXI століття", ухваленої конференцією ООН 3 навколишнього середовища i розвитку в Ріо-де-Жанейро (1992 р.), слід забезпечити наявність або розвиток ключових людських ресурсів 3 метою комплексного врахування питань навколишнього середовища і розвиток, на різноманітних етапах процесу прийняття i впровадження рішень. Передбачено підвищити ефективність освіти i підготовки технічних кадрів, особливо 3 числа жінок i дівчат шляхом включення міждисциплінарних підходів в навчальні програми навчальних закладів технічного профілю, професійно-технічних училищ, університетів та інших навчальних закладів; здійснювати системну професійну підготовку 
співробітництва урядових органів, фахівців 3 планування та менеджменту.

Висновки та перспективи подальших досліджень. Реалізація обгрунтованих в процесі дослідження еколого-економічних й організаційних важелів управління процесами природокористування сприятимуть охороні навколишнього середовища й успішному виконанню програм соціально-економічного розвитку регіону. Постає завдання активізації діяльності владних і управлінських структур, залучення територіальних громад до вирішення проблем природокористування і охорони довкілля. Подальші дослідження спрямовуватимуться на окреслення ролі органів місцевого самоврядування й зокрема територіальних громад у забезпеченні збереження навколишнього природного середовища i раціонального природокористування.

\section{ПЕРЕЛІК ВИКОРИСТАНИХ ДЖЕРЕЛ}

1. Борисова В.А. Екологічні основи природокористування в АПК. - Суми:Вид-во “Довкілля”, 2004. - 356 с.

2. Вечканов Г.С., Вечканова Г.Р. Микро- и макроэкономика: энциклопедический словарь. - СПб, 2000. $352 \mathrm{c}$.

3. Гайдуцький І.П. Системи та механізми мотивації низьковуглецевого розвитку: теорія, методологія, практика : Монографія. - К.: ТОВ “ДКС центр”, 2018. - 560 с.

4. Гайдуцький П.І., Ходаківська О.В. До екологізації агросфери через екологізацію суспільної свідомості //Матеріали всеукр. наук.-практ.конф “Екологізація аграрного виробництва в умовах інтеграції України до Європейського економічного простору”, 13 вересня 2012 р., м. Київ. - К.: ТОВ “ДКС центр”, 2013. - 144 с.

5. Данилишин Б.М., Хвесик М.А., Голян В.А. Економіка природокористування. - К.: “Кондор”, 2009. 465 c.

6. Екологічна енциклопедія: У трьох томах. Т.2. - К., 2007. - 416 с.

7. Екологічна енциклопедія: У трьох томах. Т.3. - К., 2008. - 472 с.

8. Екологічна і природно-техногенна безпека України в регіональному вимірі: Монографія/ М.А.Хвесик, А.В.Степаненко, Г.О.Обиход та ін. - К., 2014. - 340 с.

9. Економічна енциклопедія: У трьох т. Т. 2. /Редкол: С.В.Мочерний (відп.ред.) та ін. - К.: Видавничий центр «Академія», 2001. - 848 с.

10. Свропа 2020: стратегія розумного, стійкого i всеосяжного зростання. - URL : http://ec.europa.ua/evrope2020/index-en.htm. $268 \mathrm{c}$

11. Капіталізація природних ресурсів: Монографія/За заг.ред. М.А.Хвесика. - К.: ДУ ІЕПСР НАНУ, 2014. -

12. Макарова Н.С., Гармідер Л.Д., Михальчук Л.В. Економіка природокористування. - К.: Центр учбової літератури, 2007. - $322 \mathrm{c.}$

13. Мартиненко В.О. Досвід країн СС щодо сучасних механізмів управління охороною навколишнього середовища України/В.О.Мартиненко //Теорія та практика державного управління. - 2006. - Вип.1. - С.272-278.

14. Про виробництво та обіг органічної сільськогосподарської продукції та сировини: Закон України // Відомості Верховної Ради. - 2014. - № 20-21. - Ст.721.

15. Про охорону навколишнього природного середовища: Закон України// Відомості Верховної Ради України. - 1991. - № 41. - Ст.546.

16. Юлкин М.A. Мировой углеродный рынок: Состояние и тенденции развития. - URL: http://docplayer.ru/56230958-Rynok-sostoyanie-i-tendencii-razvitiya-uglerodnyy.html

17. Якимчук С.А. Зарубіжний досвід у сфері охорони навколишнього природного середовища // Есоnоmic annals-XXI. - 7-8 (2). - 2013.- C. 17-20.

18. IFOAM Basic Standards (approved by the IFOAM General Assembly, Viictoria, Canada, and August 2002). URL: www.ifoam.org.

\section{REFERENCES}

1. Borysova, V.A. (2004). Ekolohichni osnovy pryrodokorystuvannya v APK [Ecological bases of nature use in agroindustrial complex. Sumy: Vyd-vo "Dovkillya" [in Ukrainian].

2. Vechkanov, H.S. (2000). Mykro - y makroekonomyka: entsyklopedycheskyy slovar' [Micro- and macroeconomics: encyclopedic dictionary]. SPb [in Russian].

3. Hayduts'kyy, I.P. (2018). Systemy ta mekhanizmy motyvatsiyi nyz'kovuhletsevoho rozvytku: teoriya, metodolohiya, praktyka [Systems and mechanisms for the motivation of low carbon development: theory, methodology, practice].K.: TOV "DKS tsentr" [in Ukrainian].

4. Hayduts'kyy, P.I. (2013). Do ekolohizatsiyi ahrosfery cherez ekolohizatsiyu suspil'noyi svidomosti [To ecologize the agrosphere through social consciousness ecologization]. Proceedings from: Materialy vseukr. nauk.-prakt. konf "Ekolohizatsiya ahrarnoho vyrobnytstva v umovakh intehratsiyi Ukrayiny do Yevropeys'koho ekonomichnoho prostoru" - Materials of the allukr. sc.-prakt. konf. "Ecologization of agrarian production in conditions of Ukraine's integration into the European economic space" (144 p.). K.: TOV "DKS tsentr" [in Ukrainian]. 
5. Danylyshyn, B.M., \& Khvesyk, M.A., \& Holyan, V.A. (2009). Ekonomika pryrodokorystuvannya [Economics of nature management]. K.: "Kondor" [in Ukrainian].

6. Ekolohichna entsyklopediya: U tr'okh tomakh. T.2. [Environmental encyclopedia: in three volumes. Vol. 2] (2007). K. [in Ukrainian].

7. Ekolohichna entsyklopediya: U tr'okh tomakh. T.3. [Environmental encyclopedia: in three volumes. Vol. 3] (2008). K. [in Ukrainian].

8. Khvesyk, M.A., \& Stepanenko, A.V., \& Obykhod, H.O. (2014). Ekolohichna i pryrodno-tekhnohenna bezpeka Ukrayiny v rehional'nomu vymiri [Ecological and natural-technogenic safety of Ukraine in the regional dimension]. K. [in Ukrainian].

9. Mocherny, S.V. (Eds.). (2001). Ekonomichna entsyklopediya: U tr'okh t. T. 2. [Economic Encyclopedia: in three volumes. Vol. 2. ]. K.: Vydavnychyy tsentr «Akademiya» [in Ukrainian].

10. Yevropa 2020: stratehiya rozumnoho, stiykoho i vseosyazhnoho zrostannya [Europe 2020: A strategy for smart, sustainable and inclusive growth]. (n.d.). http://ec.europa.ua. Retrived from: http://ec.europa.ua/evrope2020/indexen.htm. [in Ukrainian].

11. Khvesyk, M.A. (Eds.). (2014). Kapitalizatsiya pryrodnykh resursiv [Capitalization of natural resources]. K.: DU IEPSR NANU [in Ukrainian].

12. Makarova, N.S. (2007). Ekonomika pryrodokorystuvannya [Economics of nature management]. K.: Tsentr uchbovoyi literatury [in Ukrainian].

13. Martynenko, V.O. (2006). Dosvid krayin YeS shchodo suchasnykh mekhanizmiv upravlinnya okhoronoyu navkolyshn'oho seredovyshcha Ukrayiny [Experience of EU countries on modern mechanisms of environmental protection management in Ukraine]. (2014). Teoriya ta praktyka derzhavnoho upravlinnya - Theory and practice of public administration, 1, 272-278 [in Ukrainian].

14. Pro vyrobnytstvo ta obih orhanichnoyi sil's'kohospodars'koyi produktsiyi ta syrovyny: Zakon Ukrayiny [On the production and circulation of organic agricultural products and raw materials: The Law of Ukraine]. Vidomosti Verkhovnoi Rady - Bulletin of Verkhovna Rada, 20-21, 721 [in Ukrainian].

15. Pro okhoronu navkolyshn'oho pryrodnoho seredovyshcha: Zakon Ukrayiny [About the protection of the environment: Law of Ukraine]. (1991). Vidomosti Verkhovnoi Rady - Bulletin of Verkhovna Rada, 41, 546 [in Ukrainian].

16. Yulkyn, M.A. (n.d.). Mirovoy uhlerodnyy rynok: Sostoyanye y tendentsyy razvytyya [The world carbon market: status and development trends]. http://docplayer.ru. Retrived from: http://docplayer.ru/56230958-Rynok-sostoyanie-itendencii-razvitiya-uglerodnyy.html [in Russian].

17. Yakymchuk, S.A. (2013). Zarubizhnyy dosvid u sferi okhorony navkolyshn'oho pryrodnoho seredovyshcha [Foreign experience in the field of environmental protection]. Economic annals-XXI, 7-8 (2), 17-20 [in Ukrainian].

18. IFOAM Basic Standards (approved by the IFOAM General Assembly, Viictoria, Canada, August 2002). (2002). www.ifoam.org. Retrived from: www.ifoam.org.

Одержано 15.03.2018 p. 